\title{
Initial development of gabiroba (Campomanesia adamantium) according to fertilization with nitrogen and phosphorus
}

\author{
Jéssica Rodrigues de Mello Duarte ${ }^{1}$, Scarlet de Aguiar Basílio ${ }^{1}$, Nei Peixotoํㅜ, Mariana Pina da \\ Silva Berti ${ }^{1}$
}

${ }^{1}$ Universidade Estadual de Goiás, Unidade Universitária Ipameri, Ipameri, Goiás, Brasil. E-mail: jessicamello13@hotmail.com,
scarletaguiar@y ahoo.com.br, nei.peixoto48@gmail.com, mariana.berti@ueg.br

Received: 20/01/2021; Accepted: 25/05/2021.

\begin{abstract}
Campomanesia adamantium (Cambess.) Berg O. is a native of Savanna, popularly known as gabiroba, guavira, or gabiroba-do-campo, and has many uses, with its fruit being consumed fresh or processed. This study aimed to evaluate different doses of phosphorus and nitrogen in the initial development of gabiroba (Campomanesia adamantium) cultivated in pots. Five doses of phosphorus $\left(0,100,200,300\right.$, and $400 \mathrm{~kg} \mathrm{ha}^{-1}$ of $\left.\mathrm{P}_{2} \mathrm{O}_{5}\right)$ and three doses of nitrogen $\left(0,100\right.$, and $200 \mathrm{~kg} \mathrm{ha}^{-1}$ of $\left.\mathrm{N}\right)$ were tested. The experimental design used was completely randomized in a $5 \times 3$ factorial scheme with six replications. The evaluations were carried out 120 days after plant emergence, and the variables analyzed were stem diameter, plant height, and number of leaves. Data were subjected to analysis of variance and F-test. The means were compared by the Tukey test at $p<0.05$. Regression analyzes were adjusted for phosphorus doses. The gabiroba responds significantly to the addition of phosphorus, with the dose of $400 \mathrm{~kg} \mathrm{ha}^{-1}$ of $\mathrm{P}_{2} \mathrm{O}_{5}$ providing the highest height and the dose of $300 \mathrm{~kg} \mathrm{ha}^{-1}$ of $\mathrm{P}_{2} \mathrm{O}_{5}$ providing the greatest stem diameter and the number of leaves. Up to 120 days old, gabiroba seedlings do not respond significantly to nitrogen fertilization.
\end{abstract}

Keywor ds: Myrtaceae, Vegetable nutrition, Fruit growing.

\section{Desenvolvimento inicial da gabiroba (Campomanesia adamantium) em resposta à adubação com nitrogênio e fósforo}

\section{RESUMO}

A Campomanesia adamantium (Cambess.) O. Berg é uma espécie nativa do Cerrado, popularmente conhecida como gabiroba, guavira ou gabiroba-do-campo e possui diversas utilizações, sendo seu fruto consumido in natura ou processado. O estudo objetivou avaliar diferentes doses de fósforo e nitrogênio no desenvolvimento inicial de gabiroba (Campomanesia adamantium) cultivada em vasos. Foram testadas cinco doses de fósforo (0, 100, 200, 300 e $\left.400 \mathrm{~kg} \mathrm{ha}^{-1} \mathrm{de} \mathrm{P}_{2} \mathrm{O}_{5}\right)$ e três doses de nitrogênio $\left(0,100\right.$ e $200 \mathrm{~kg} \mathrm{ha}{ }^{-1}$ de $\left.\mathrm{N}\right)$. O delineamento experimental utilizado foi inteiramente casualizado em esquema fatorial $5 \times 3$ com seis repetições. As avaliações foram realizadas aos 120 dias após a emergência das plantas e as variáveis analisadas foram diâmetro do caule, altura da planta e número de folhas. Os dados foram submetidos à análise de variância (teste F) e teste comparativo de médias Tukey para $p<0.05$. Para as doses de fósforo foram ajustadas análises de regressão. A gabiroba responde significativamente à adição de fósforo, sendo que a dose de $400 \mathrm{~kg} \mathrm{ha}^{-1} \mathrm{de}_{2} \mathrm{O}_{5}$ proporciona maior altura e a dose de $300 \mathrm{~kg} \mathrm{ha}^{-1}$ de $\mathrm{P}_{2} \mathrm{O}_{5}$ proporciona maior diâmetro do caule e número de folhas. Até os 120 dias, as mudas de gabiroba não respondem significativamente à adubação nitrogenada

Palavras-chave: Myrtaceae, Nutrição vegetal, Fruticultura. 


\section{Introduction}

Campomanesia adamantium (Cambess.) Berg O. is native from the Cerrado, belonging to the Myrtaceae family and popularly known as gabiroba, guavira, or gabiroba-do-campo (Lion Araujo et al., 2019a), occurring in the states of São Paulo, Tocantins, Mato Grosso, Mato Grosso do Sul, Goiás, Distrito Federal, Bahia, Minas Gerais, and Santa Catarina, reaching the adjacent regions of Argentina and Paraguay (Oliveira et al., 2011).

It has a shrubby growth habit, with a height between 0.5 and $1.5 \mathrm{~m}$; its flowering occurs between September and October, and its fruiting occurs between November and December, forming succulent, citrusy, and slightly sweet fruits (Oliveira et al., 2017). Despite its potential, its use is restricted to extractivism (Leão-Araújo et al., 2019b), and technical and scientific information addressing the agronomic and production aspects of gabiroba are scarce.

There are several uses of the fruit, being consumed fresh or processed in the form of juices, liqueurs, ice cream, and jellies. Its use is also highlighted in the recovery of degraded areas, environmental protection areas, and the formation of domestic and commercial orchards (Souza et al., 2020). It also has medicinal properties, being used as an anti-inflammatory, antidiarrheal, and antiseptic (Vieira et al., 2011).

The tolerance to low fertility found in native Cerrado species does not eliminate the possibility of a response to fertilization (Dalanhol et al., 2017). Expressive increases in plant development can be achieved through mineral fertilization, reflecting on better development, precocity, and greater field survival (Barbosa et al., 2003). Thus, nitrogen use in plant development can be crucial since it is considered one of the nutrients most in demand by plants.

Nitrogen is part of the chemical composition of several cell constituents, such as nucleotides and amino acids, which form structures of nucleic acids and proteins, respectively; it is mainly absorbed as ammonium $\left(\mathrm{NH}_{4}{ }^{+}\right)$and nitrate $\left(\mathrm{NO}_{3}{ }^{-}\right)$(Kerbauy, 2013). After absorption, nitrogen is quickly incorporated into growing tissues, such as expanding leaves, root tips, and meristems, and excessive nitrogen fertilization can negatively affect rooting, making proper balance and nutrient supply es sential (Emer et al., 2019).

Phosphorus is an essential nutrient that directly participates in compounds and vital reactions for plants, absorbed predominantly in the ionic form of $\mathrm{H}_{2} \mathrm{PO}_{4}{ }^{-}$ (Kerbauy, 2013), which is accumulated in the cortical cells of the root and transferred within it to the xylem through the symplast, reaching the leaves or growing regions, together with nitrogen being the most readily redistributed element (Taiz and Zeiger, 2010).
Due to its varied use and potential economic importance, studies about Campomanesia sp. are essential for its insertion in the consumer market, preserving its natural state and implementing future commercial crops (Oliveira et al., 2011). Furthermore, it is known that it is adapted to its nutritional conditions because it is a plant native to the Cerrado. However, studies related to plant nutritional needs are still insufficient. Within this context, this study aimed to evaluate different doses of phosphorus and nitrogen in the initial development of gabiroba (Campomanesia adamantium) cultivated in pots.

\section{Material and Methods}

The study was carried out in a greenhouse located at the State University of Goiás, University Unit of IpameriGO. The climate is defined as Humid Tropical (Aw), consisting of high temperatures with rain in summer and drought in winter. The maximum and minimum temperatures in the externalenvironment during the plant development period were $33.7^{\circ} \mathrm{C}$ and $17.1^{\circ} \mathrm{C}$, respectively. The greenhouse used has modular characteristics, prefabricated and with lateral and superior coverage with polyethylene under additional superior protection of $50 \%$ shade.

The experimental design used was completely randomized in a $5 \times 3$ factorial scheme with six replications, each plot consisting of a pot with a capacity of 8 liters. Five doses of phosphorus (0, 100, 200, 300, and $400 \mathrm{~kg} \mathrm{ha}^{-1}$ of $\left.\mathrm{P}_{2} \mathrm{O}_{5}\right)$ were tested in the form of simple superphosphate (P: $21 \%$ ) and three doses of nitrogen ( 0 , 100 , and $200 \mathrm{~kg} \mathrm{ha}^{-1}$ of $\mathrm{N}$ ) in the form of urea ( $\left.\mathrm{N}: 45 \%\right)$.

Soil was collected and prepared fifteen days before sowing. Soil analysis was performed, and it was classified as Latossolo Vermelho-Amarelo, of medium texture, whose chemical characteristics were $\mathrm{pH} \mathrm{CaCl} 2=$ 4.9; $\mathrm{P}\left(\mathrm{mg} \mathrm{dm}^{-3}\right)=1.2 ; \mathrm{K} ; \mathrm{Al} ;$ Here; $\mathrm{Mg}\left(\mathrm{cmolc} / \mathrm{dm}^{-3}\right)=$ $0.03 ; 0.1 ; 0.7 ; 0.3 ; \mathrm{H}+\mathrm{AL}$, and $\mathrm{SB}=2.1 ; 3.13$, respectively, $\mathrm{V}(\%)=32.91$ and organic matter $\left(\mathrm{g} \mathrm{dm}^{-3}\right)$ $=12.0$.

Seeds were collected from a population of native plants, occurring in the area belonging to the State University of Goiás, University Unit of Ipameri. Ripe fruits were harvested, removing the seeds with the pulp and leaving it to ferment for a day in the pulp juice. After fermentation, they were washed and placed to dry on paper towels for two days, and then sowing was carried out, with three seeds per pot. After germination and emergence, thinning occurred, leaving only one plant per pot.

Fertilization was carried out with $300 \mathrm{~kg} \mathrm{ha}^{-1}$ of potassium chloride (K: 58\%) and $100 \mathrm{~kg} \mathrm{ha-1}$ of micronutrients (Ca: $7.1 \%$; S: $5.7 \%$; $\mathrm{B}: 1.8 \%$; $\mathrm{Cu}: 0.8 \%$; 
Mn: 2.0\%; Mo: 0.1\%; Zn: 9.0\%). Phosphorus was added in a single plot at sowing, and nitrogen was split in three times, the first plot at sowing with $50 \%$ of the dosage, the second plot at 70 days after emergence with $25 \%$ of the dosage, and the last plot at 100 days after emergence, with $25 \%$ of the dosage.

The evaluations were carried out 120 days after plant emergence. The variables analyzed were stem diameter, using a caliper graduated in millimeters and measuring 1 (one) $\mathrm{cm}$ above the ground; plant height, using a ruler graduated in centimeters and measuring the ground level until the insertion of the last leaf and Number of leaves, in which the leaves of all plants were counted. Data were subjected to analysis of variance and F-test. The means were compared by the Tukey test at $p<0.05$. Log 10 transformed data referring to the variable "plant height". Regression analyzes were adjusted for phosphorus doses. Statistical analyzes were processed using the statistical analysis program $R$.

\section{Results and Discussion}

Table 1 presents the results of all characteristics evaluated for the different factors and interactions under study. Significant differences were found among the levels of phosphate fertilization. Nitrogen fertilization and the interaction between factors was not significant, indicating that factors under study act independently and thatnitrogen fertilization did not significantly change the analyzed variables. Treatments differed in height, stemdiameter, and number of leaves in response to phosphate fertilization.

Plant height differed between treatments in response to phosphate fertilization (Figure 1). The highest height observed between treatments was $9.29 \mathrm{~cm}$, reached 120 days after emergence under a dose of $400 \mathrm{~kg} \mathrm{ha}^{-1}$ of $\mathrm{P}_{2} \mathrm{O}_{5}$. Fromthis result, it is concluded that $C$. adamantium plants require high doses of phosphorus for their growth, which can be explained by considering that phosphorus acts in metabolic processes as an energy supplier and component of numerous protein complexes (Vieira et al. al., 2011).

A study by Vieira et al. (2011) using P and N doses in Campomanesia adamantium plants evaluated 261 days after transplanting obtained the best results for plant height at the dose of 380 and $84 \mathrm{~kg} \mathrm{ha}^{-1}$ of phosphorus $\left(\mathrm{P}_{2} \mathrm{O}_{5}\right)$ and nitrogen $(\mathrm{N})$, respectively. Plant height is considered one of the most important parameters to estimate the initial growth of seedlings. However, due to variations depending on the species and production methods, it must be combined with other parameters, such as diameter (Emer et al., 2020).

The stem diameter variable was significantly influenced by phosphorus doses (Figure 2), and the dose of $312 \mathrm{~kg} \mathrm{ha}^{-1}$ of $\mathrm{P}_{2} \mathrm{O}_{5}$ showed the best results through regression analysis. The larger diameter of the stem favors the stabilization and translocation of photoassimilates to the growing seedling (Carnevali et al., 2015), which makes it a desirable characteristic in seedlings due to the high correlation with field survival. It is also observed that the height is directly related to the diameter and number of leaves; that is, the larger the plant, the greater the diameter and number of leaves (Guimarães et al., 2019).

As for the Number of leaves, the variable was also significantly influenced by the doses of phosphorus (Figure 3), with the best result being obtained at the dose of $293 \mathrm{~kg} \mathrm{ha}^{-1}$ of $\mathrm{P}_{2} \mathrm{O}_{5}$.

Table 1. Summary of the analy sis of variance and the comparison test of global means by dose of the analy zed parameters: Plant height $(\mathrm{cm})$, Stem diameter $(\mathrm{mm})$, and Number of leaves of gabiroba subjected to application of doses of phosphorus and nitrogen, developed in the experimental area of the State University of Goiás (UEG).

\begin{tabular}{|c|c|c|c|}
\hline Treatments & $\begin{array}{l}\text { Plant height } \\
(\mathrm{cm})\end{array}$ & $\begin{array}{l}\text { Diameter } \\
(\mathrm{mm})\end{array}$ & $\mathrm{N}^{\circ}$ of leaves \\
\hline \multicolumn{4}{|c|}{$\mathrm{P}_{2} \mathrm{O}_{5}$ doses $\left(\mathrm{kg} \mathrm{ha}^{-1}\right)$} \\
\hline 0 & $5.06^{(1)}$ & $1.75^{(2)}$ & $10.7^{(3)}$ \\
\hline 100 & 5.57 & 2.14 & 12.5 \\
\hline 200 & 8.74 & 2.67 & 17.4 \\
\hline 300 & 8.67 & 2.47 & 15.7 \\
\hline 400 & 9.29 & 2.59 & 15.9 \\
\hline \multicolumn{4}{|l|}{$\mathrm{N}$ doses $\left(\mathrm{kg} \mathrm{ha}^{-1}\right)$} \\
\hline 0 & 6.99 & 2.23 & 14.3 \\
\hline 100 & 8.16 & 2.48 & 14.5 \\
\hline 200 & 7.25 & 2.26 & 14.6 \\
\hline \multicolumn{4}{|l|}{ F-value } \\
\hline $\mathrm{P}_{2} \mathrm{O}_{5}$ doses $(\mathrm{A})$ & $7.249 * *$ & $10.432 * *$ & $6.814 * *$ \\
\hline $\mathrm{N}$ doses $(\mathrm{B})$ & $1.154^{\mathrm{ns}}$ & $2.301^{\mathrm{ns}}$ & $0.032^{\mathrm{ns}}$ \\
\hline $\mathrm{AxB}$ & $0.765^{\mathrm{ns}}$ & $0.854^{\mathrm{ns}}$ & $0.403^{\text {ns }}$ \\
\hline $\mathrm{CV}(\%)$ & 41.91 & 21.45 & 30.85 \\
\hline
\end{tabular}




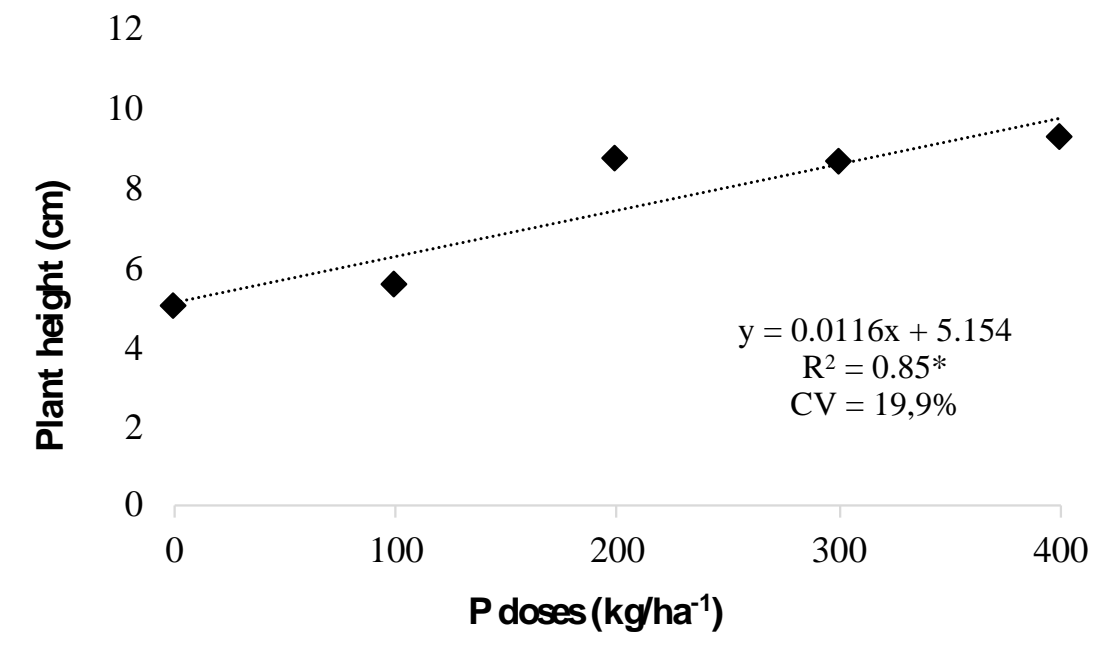

Figure 1. Plant height of gabiroba plants at 120 days after emergence according to the doses of phosphorus.

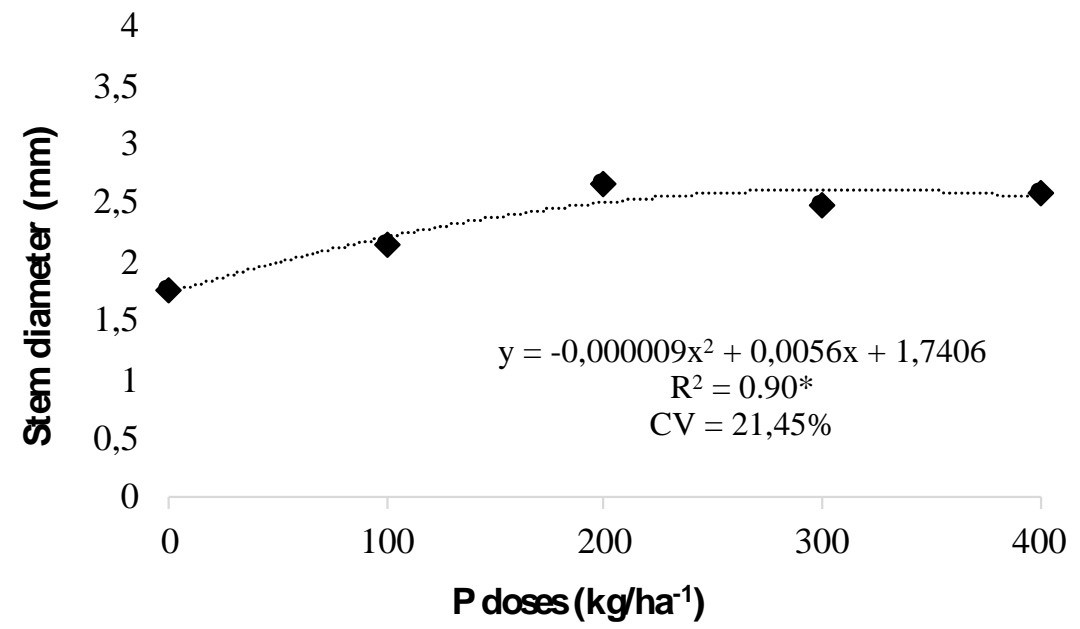

Figure 2. Diameter of the stem of gabiroba plants at 120 days after emergence according to the doses of phosphorus.

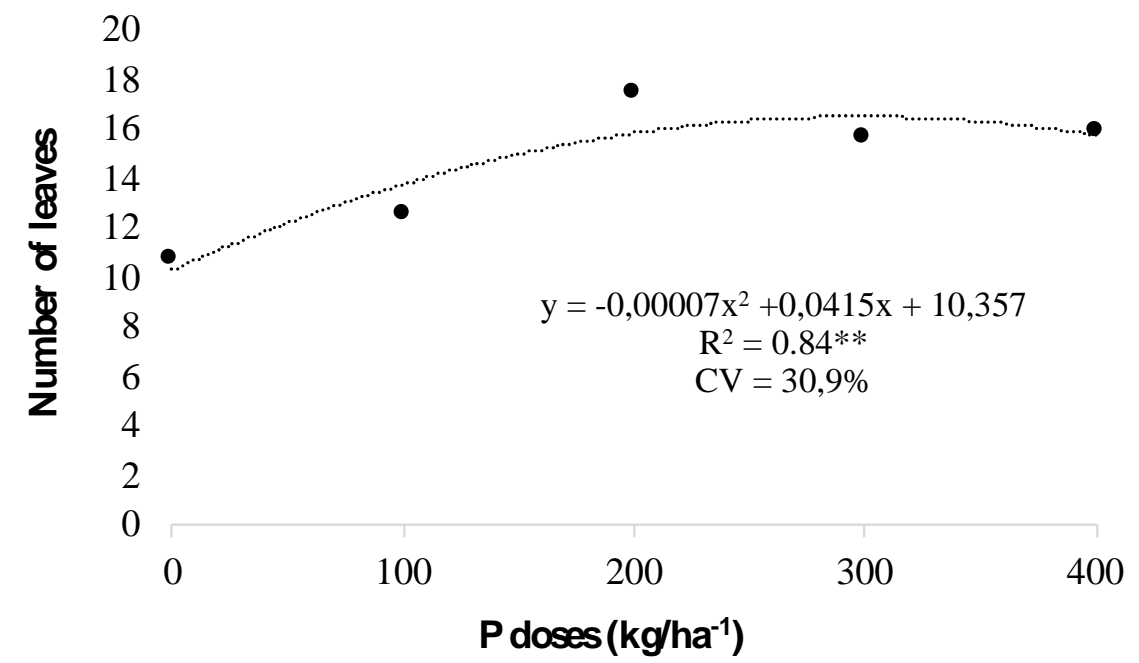

Figure 3. Number of leaves in gabiroba plants at 120 days after emergence according to the doses of phosphorus. 
The seedlings responded positively to the application of phosphorus for the variables: height, stem diameter, and Number of leaves, presenting, in the initial phase of growth, relatively high demand for the nutrient, and the initial availability found in the soil is insufficient to meet the nutritional requirements of this species at this stage. The same behavior was observed in Psidium guajava L. (guava) (Batista et al., 2011). Generally, native Cerrado species respond with increased biomass production when nutrient $P$ is supplied (Melo et al., 2019).

Native species have different nutritional requirements (Cruz et al., 2006). In this sense, some species respond to nitrogen fertilization (Fonseca et al., 2019), while others do not respond, as we found with the cagaita (Eugenia dysenterica), species used in the experiment. This was also verified in studies that evaluated the effect of nitrogen fertilization on other species, such as cagaita (Duboc and Guerrini, 2007). Considering these studies, we can infer that the difference between species is possibly more related to the genetic characteristics of each one, in addition to certain factors, such as the absorption, transport, and use of nutrients (Lima et al., 2008).

\section{Conclusions}

The gabiroba responds significantly to the addition of phosphorus, with the dose of $400 \mathrm{~kg} \mathrm{ha}^{-1}$ of $\mathrm{P}_{2} \mathrm{O}_{5}$ providing greater height and the dose of $300 \mathrm{~kg} \mathrm{ha}^{-1}$ of $\mathrm{P}_{2} \mathrm{O}_{5}$ providing greater diameter of the stem and number of leaves. Up to 120 days old, gabiroba seedlings do not respond significantly to nitrogen fertilization.

\section{Authors' Contribution}

Jéssica Rodrigues de Mello Duarte contributed to the study data collection, analysis, and writing. Scarlet de Aguiar Basílio participated in data collection and article review. Nei Peixoto contributed to the review of the manuscript and guided all stages of the study. Author Mariana Pina da Silva Berti reviewed and wrote the project and manuscript and guided all stages of development.

\section{Bibliographic References}

Barbosa, Z., Soares, I., Crisóstomo, L.A. 2003. Crescimento e absorção de nutrientes por mudas de gravioleira. Revista Brasileira de Fruticultura, 25 (3), 519-522. DOI: https://doi.org/10.1590/S0100-29452003000300039

Batista, M.A.V., Prado, R.M., Leite, G.A. 2011. Resposta de mudas de goiabeira a aplicação de fósforo. Bioscience Journal, 27 (4), 635-641.
Carnevali, T.O., Vieira, M.C., Luciano, A.T., Gonçalves, W.V., Rodrigues, W.B., Ramos, M.B.M. 2015. Crescimento inicial de Campomanesia xanthocarpa O. Berg sob diferentes composições de substratos. Revista Brasileira de Plantas

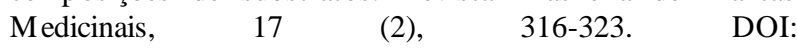
https://doi.org/10.1590/1983-084X/12_080

Cruz, C.A.F., Paiva, H.N., Guerrero, C.R.A. 2006. Efeito da adubação nitrogenada na produção de mudas de sete-cascas (Samanea inopinata (Harms) Ducke). Revista Árvore, 30 (4), 537-546. DOI: https://doi.org/10.1590/S010067622006000400006

Dalanhol, S.J., Nogueira, A.C., Gaiad, S., Kratz, D. 2017. Efeito de micorrizas e da fertilização no crescimento de mudas de Campomanesia xanthocarpa (Mart.) O.Berg., produzidas em diferentes substratos. Ciência Florestal, 27 (3), 931-945. DOI: https://doi.org/10.5902/1980509828665

Duboc, E., Guerrini, I.A. 2007. Crescimento inicial e sobrevivência de espécies florestais de mata de galeria no domínio do cerrado em resposta à fertilização. Energia na Agricultura, 22 (1), 42-60.

Emer, A.A., Avrella, E.D., Fior, C.S., Schafer, G. 2019. Nitrogen fertilization for ministrains of Campomanesia aurea $\mathrm{O}$. Berg and its influence on productivity and rooting of minicuttings at different seasons of the year. Brazilian Journal of Agricultural Sciences, 14 (2), 1-8. DOI: https://doi.org/10.5039/agraria.v14i2a5632

Emer, A.A., Winhelmann, M.C., Tedesco, M., Fior, C.S., Schafer, G. 2020. Controlled release fertilizer used for the growth of Campomanesia aurea seedlings. Ornamental Horticulture, 26 (1), 35-44. DOI: https://doi.org/10.1590/2447536X.v26i1.2020

Fonseca, W.L., Oliveira, A.M., Sousa, T.O., Zuffo, A.M., Santos, R.F., Carvalho, R.M., Almeida, F.A., Oliveira Neto, N.M., Guerra, L.O., Gomes, T.S. 2019. Decomposed buriti stem and nitrogen application rates on the growth of Eugenia dysenterica DC (Myrtaceae) seedlings. Journal of Agricultural

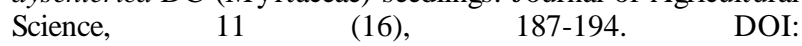
https://doi.org/10.5539/jas.v11n16p 187

Guimarães, R.R., Vieira, M.C., Rocha, E.C., Peixoto, N., Pires, L.L. 2019. Cultivo inicial de mangabeira consorciada com adubos verdes no Cerrado do sudeste de Goiás. Revista IberoAmericana de Ciências Ambientais, 10 (2), 65-73. DOI: https://doi.org/10.6008/CBPC2179-6858.2019.002.0007

Kerbauy, G.B. 2013. Fisiologia Vegetal. Rio de Janeiro, Guanabara Koogan.

Leão-Araújo, E.F., Santos, W.V., Ferreira, L.B.S., Ferreira, E.A.S., Gomes-Júnior, F.G., Peixoto, N., Souza, E.R.B. 2019a. Embebição e emissão da raiz primária de sementes de Campomanesia adamantium em função da temperatura. Revista de Ciências Agrárias, 42 (2), 402-409. DOI: https://doi.org/10.19084/rca.15654

Leão-Araújo, E.F., Souza, E.R.B., Peixoto, N., Gomes-Júnior, F.G. 2019b. Phy siological potential of seeds and morphological characterization of Campomanesia adamantium seedlings. Revista Brasileira de Fruticultura, 41 (4), 1-7. DOI: https://doi.org/10.1590/0100-29452019007 
Lima, L.S.H., Franco, E.T.H., Schumacher, M.V. 2008. Crescimento de mudas de Euterpe edulis Martius em resposta a diferentes doses de fósforo. Ciência Florestal, 18 (4), 461-470. DOI: https://doi.org/10.5902/19805098430

Melo, R.M., Vieira, M.C., Carnevali, T.O., Gonçalves, W.V., Torales, E.P., Tolouei, S.E.L., Santos, C.C. 2019. Calagem e textura do substrato afetam o desenvolvimento de Campomanesia adamantium (Cambess.) O. Berg. Revista de Ciências Agrárias, 42 (1), 101-110. DOI: https://doi.org/10.19084/RCA18283

Oliveira, J.D., Alves, D.K.M., Miranda, M.L.D., Alves, J.M., Xavier, M.N., Cazal, C.M., Alves, C.C.F. 2017. Chemical composition of essential oil extracted from leaves of Campomanesia adamantium subjected to different hydrodistillation times. Ciência Rural, 47 (1), 1-7. DOI: https://doi.org/10.1590/0103-8478cr20151131
Oliveira, L.J., Silva, S.M., Netto, A.P.C., Silva, S.M. 2011. Características agronômicas e atividade da redutase do nitrato em plantas de Campomanesia sp. sob estresse hídrico. Agrarian, 4 (11), 43-53.

Souza, J.L.C.S., Vieira, M.C., Souza, E.R.B., Guimarães, R.N., Naves, R.V. 2020. Cutting in fruit of the Cerrado. Brazilian Journal of Development, 6 (3), 15531-15544. DOI: https://doi.org/10.34117/bjdv6n3-432

Taiz, L., Zeiger, E. 2010. Fisiologia Vegetal, terceira ed. Artmed, Porto Alegre.

Vieira, M.C., Perez, V.B., Heredia, Z.N., Santos, M.C., Pelloso, I.A.O., Pessoa, S.M. 2011. Nitrogênio e fósforo no desenvolvimento inicial da guavira [Campomanesia adamantium (Cambess.) O. Berg] cultivada em vasos. Revista Brasileira de Plantas Medicinais, 13, 542-549. DOI: https://doi.org/10.1590/S1516-05722011000500007 